\author{
Visión Electrónica \\ Más que un estado sólido \\ https://doi.org/10.14483/issn.2248-4728
}

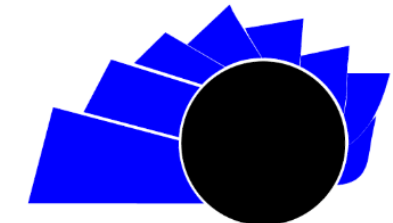

VISIÓN ELECTRÓNICA

\title{
Martha C. Nussbaum. The Monarchy of Fear, A philosophical look at the current political crisis. Bogotá: Editorial Planeta Colombia, 2019, 303 Pages.
}

\author{
Rosendo López-González iD ${ }_{1}$, Astrid Ramírez-Valencia ${ }^{(\mathbb{D}}{ }_{2}$
}



The book is organized into six chapters, a preface, and an introduction; at the end are the acknowledgments and explanatory notes, true sources that encourage further research on the topic raised by Nussbaum.

A bit of history: It was 2016 and in Kyoto, far away from the United States, Kazuo Inamori, a famous
Japanese businessman who invented an award to recognize the work of those who have contributed to the scientific, cultural and spiritual improvement of humanity was about to present the awards.

At the same time, Martha Nussbaum, who was also there in Kyoto in a panic, was getting ready to receive one of the prizes awarded by the Buddhist monk Inamori "I put on my evening dress and smiled my best for the official photo portrait" [1, p.13]. Martha said.

What interests me now is: Why was Martha scared to death? That day, precisely, the elections were taking place in the United States; she traveled in confidence that fear and anger would be ignored, but the opposite happened: unrest won. According to the preface of The Monarchy... that was one of the author's motivations for writing this book.

The introduction begins with a dismaying statement: "In America today, there is much fear, and it is a fear that is often intermingled with anger, guilt (which is attributed to another) and envy [1, p.26]. After describing and highlighting the causes of intermingled fear, it is worth stopping at one of its roots, according to Professor Nussbaum: immigrants, racial minorities, and women.

Summarizing, and to finish the introduction, it is worth reading carefully a Socratic dialogue, imagined

1 BSc. In Chemical engineering, Universidad del Atlántico, Colombia. MSc. in Latin American Philosophy, Universidad Santo Tomás, Colombia. MSc. In Chemistry Teaching. Current position: Professor at Universidad Distrital Francisco José de Caldas, Colombia. E-mail: rlopezg@udistrital.edu.co

2 BSc. In Spanish-English, Universidad Distrital Francisco José de Caldas, Colombia. MSc. In Linguistics Applied to the Teaching of English, Universidad Distrital Francisco José de Caldas, Colombia. Ph.D. (c) In Language and Culture, Universidad Pedagógica y Tecnológica de Colombia, Tunja, Colombia. Current position: Member of the group GITEM++, Universidad Distrital Francisco José de Caldas, Colombia. E-mail: aramirezv@udistrital.edu.co

Cite this article as: R. López-González, A. Ramírez-Valencia, "Martha C. Nussbaum. The Monarchy of Fear, A philosophical look at the current political crisis. Bogotá: Editorial Planeta Colombia, 2019, 303 Pages", Visión Electrónica, vol. 14, no. 1, pp. 134-136, January 2020. https://doi.org/10.14483/22484728.16999 
between a defender of fear (DF) and the author Martha Nussbaum (MN). In the long run, it is a discussion about the role of emotions in a democratic society; MN ends by stating that laws are important, but they need to convince people intellectually and emotionally.

The second chapter of The Monarchy of Fear begins by pointing out the genealogy of fear and its biological reasons. The author states that in so-called democratic countries, starting with the United States, fear "can be manipulated by both true and false information, and can produce both appropriate and inappropriate reactions" [1, p.70].

On the other hand, teacher Nussbaum asserts that when she tries to reflect on emotions the Roman poet Titus Lucretius Caro (99 - 55 B.C.) is her inspiration. At the same time, Lucretius proclaims as his muse the Greek philosopher Epicurus (341-270 B.C.). The latter is called by some the philosopher of happiness since he proclaims in his writings that the basis of coexistence is placidity. In one of the aphorisms, Epicurus assures that philosophy with speeches and reasoning procures a happy life. If we stick to the idea of a theoretical framework, in an investigation, in this chapter we find clear germs on a theoretical framework.

It should also be said that this section concludes with an analysis of President Trump's discourse on fear:

"It feeds fear by creating the sense that there is a great and unlimited danger (the south, the east), as well as an eminent and pressing one. It then immediately enters into the rhetoric of guilt and self-defense, for fear breeds anger" [1, p.84].

The third chapter, entitled Anger, the Daughter of Fear, begins with an explanation of the neurasthenia of American society; "men blame women, women blame men" [1, p. 89]. The author explains the chain of blame: the right-wing points to Muslims, the left-wing points to those who point to Muslims. Immigrants blame the instability of their lives on the political regime; the ruling class blames immigrants for the instability of their lives; this atmosphere of hysteria, according to the author, is incited by fear which awakens in the citizen anxiety of revenge and retaliation.

3 "I Have a Dream" was a speech given by civil rights activist Martin Luther King on August 28, 1963, from the steps of the Lincoln Memorial during the March on Washington for Jobs and Freedom.
From all the above, the author concludes that fear is a disruptive factor in the cohesion of bourgeois democracies and contaminates democratic politics, in contrast to the absence of anger as an example: Mohandas Gandhi, Martin Luther King Jr., and Nelson Mandela.

The third chapter ends with a very important reflection for the current situation, called the protest without revenge. The approach is so beautiful that there are no words to describe it. It is preferable that the reader look for the book and have the possibility to taste it in silence.

Synthesizing the third chapter, the author reinterprets Martin Luther and recreates his famous "I Have a Dream" speech, exemplifying it as the protest without revenge when he states:

\section{Let us not seek to satisfy our thirst for freedom by drinking from the cup of bitterness and hatred. We must forever conduct our struggle on the high road of dignity and discipline. We must not allow our creative protest to degenerate into physical violence. Again, and again we must rise to the majestic heights where physical strength meets soul strength ${ }^{3}$}

Professor Nussbaum, in the fourth chapter, with an extraordinary delicacy in comparing words, deals with the politics of exclusion. She explains the theme in feudal and monarchical societies where the divine power of the king elevates him in "modern democratic societies" (MDS). For the author, despite the existence of equal respect and dignity for people in the norms, in practice cases equal to feudalism occur.

To clarify: very far from the Marxist examination that gives preponderance to economic factors in the theme of exclusion, Professor Martha has another viewpoint. Her concern is that emotions drive and shape exclusion to the point of crimes of hatred in the MSD.

However, in the search for the emotional roots that drive and configure exclusion in the so-called MSD, the author draws on philosophical and psychological conceptions in order to give some explanations, affirming that in many cases exclusion does not depend on the actions of social groups such as the differentiated 
actions of Muslims or black men, but on the close emotional relationship that the vulnerability and mortality of one's own body provoke in the human being. In such a way that the exclusionary idea of moving away from some social groups saying that they are stinking and acting like beasts is a projection of what is in the pointing group.

A synthesis of the previous approaches can be found in The Monarchy... when Professor Nussbaum states

"Our society (like most societies) has an unedifying history of exclusion based on race, gender, sexual orientation, disability, age, and religion. In our current political moment, the demands for equality and dignity made by hitherto excluded groups are being answered with worrying frequency by hate propaganda (and even crimes)" [1, pp.123-124].

In the following chapters (the last three), Professor Nussbaum continues to delve into the so-called emotions that promote exclusion in "modern democratic societies", and that ultimately act as interference in the exercise of democracy; the treatment of envy in society in the manner of John Rawls, in his famous book Theory of Social Justice, deserves a special mention.

An important example for analysis and study is the emotional relationships that are inserted in American high schools among young people, according to the author: "(..) the cultures of these schools often highlight achievements and triumphs that are very competitive and positional, such as popularity, sexual magnetism or sportsmanship" [1, p. 173]. The great frenzied competition in the institutes is to enter the elite universities which is closely related to the cost that creates a problem of inequality in access to higher education.

Professor Nussbaum closes her creative book by conveying to her readers a message of hope, love, and imaginative vision. As it is her unparalleled view of the society in which she lives, I recommend the book.

\section{References}

[1] M. C. Nussbaum, "A philosophical look at the current political crisis", Bogotá: Editorial Planeta Colombia, 2019. 